Галина Гайович

Інститут державного управління

у сфері цивільного захисту, м. Київ

ORCID ID 0000-0003-0135-6191

Катерина Шихненко

Інститут державного управління

у сфері цивільного захисту, м. Київ

ORCID ID 0000-0002-8623-2907

DOI 10.24139/2312-5993/2019.07/185-195

\title{
ШЛЯХИ ПОЛІПШЕННЯ НАВИЧОК КОМУНІКАЦІЇ ДЕРЖАВНОЮ МОВОЮ ФАХІВЦІВ СФЕРИ ЦИВІЛЬНОГО ЗАХИСТУ
}

\begin{abstract}
Метою статті є аналіз мовленнєвої комунікації як фрактору профресійної успішності державних службовців сфери цивільного захисту та надання пропозицій щодо можливих варіантів їхньої мовленнєвої підготовки на засадах компетентнісного підходу в умовах функціонального навчання. Використано методи спостереження, моделювання, аналізу й синтезу. Зазначено, що вільне володіння державною мовою $\epsilon$ особливо важливим для державних службовців сфери ДСНС у зв'язку зі специфрікою їхньої діяльності, яка вимагає, щоб рішення в умовах надзвичайної ситуації швидко готувалися з урахуванням найсвіжіших та точних відомостей про перебіг події, оперативно затверджувалися й реалізовувалися. Подальші дослідження можуть бути спрямовані на розробку структури професійно-комунікативної компетентності фрахівців сфери цивільного захисту й окреслення шляхів ії вдосконалення.
\end{abstract}

Ключові слова: професійно-комунікативна компетентність, мовні знання, мовленнєва комунікація, функціональне навчання, компетентнісний підхід.

Постановка проблеми. Зміни, які сьогодні проходять в українському суспільстві, актуалізують необхідність реформування системи Державної служби України з надзвичайних ситуацій (далі - ДСНС). 3 цією метою розпорядженням Кабінету Міністрів України від 25 січня 2017 р. № 61-р було схвалено «Стратегію реформування системи Державної служби 3 надзвичайних ситуацій», відповідно до якої серед інших важливих завдань передбачено «удосконалення механізму взаємодії з іншими структурами забезпечення національної безпеки шляхом подальшого розвитку державного центру управління в надзвичайних ситуаціях ДСНС, утворення відповідних регіональних центрів і налагодження їх взаємодії з Головним ситуаційним центром та іншими ситуаційними центрами складових сектору безпеки і оборони», «створення та забезпечення функціонування ... центру обробки даних, комплексної підсистеми інформаційної підтримки прийняття рішень з питань надзвичайних ситуацій...» (Розпорядження Кабінету Міністрів України «Про схвалення Стратегії реформування системи Державної служби України з надзвичайних ситуацій», 2017) тощо. Виконання цих вимог, які 
напряму пов'язані з професійно-комунікативною компетентністю, неможливе без наявності в арсеналі фахівців сфери цивільного захисту мовних та мовленнєвих умінь і навичок. Уміння висловлювати свої думки державною мовою - це проблема, що зачіпає так чи інакше кожного фахівця. До останнього часу вимога спілкуватися державною мовою в професійній сфері не стояла так гостро. Сьогодні ж ця тема стала особливо актуальною. Чи не найголовнішою причиною цього стало українське мовне законодавство, у якому висунуто вимогу щодо вільного володіння українською мовою у професійній сфері. Зважаючи на такі зміни в суспільному житті, актуально звучить сьогодні проблема підготовки професіонала, у загальний контекст компетентностей якого органічно впліталися 6 мовні та мовленнєві навички.

Аналіз актуальних досліджень. Мовні та мовленнєві компетенції особистості стали предметом публічного обговорення та пильної уваги науковців різних галузей, письменників та всіх небайдужих до виражальних можливостей слова й до престижу своєї мови. Теоретичні питання комунікативної лінгвістики досліджували в своїх працях такі українські науковці, як Л. Мацько, Ф. Бацевич, С. Єрмоленко, Л. Струганець та інші.

Окремим проблемам формування професійної компетентності особистості з високим рівнем мовної підготовки присвячені, наприклад, студії М. Пентилюк (Пентелюк, 2010), яка зосереджує увагу на компетентнісному підході до формування мовної особистості. Р. Вінклер (Winkler, 2004) аналізує питання міжособистісної професійної комунікації, О. Федоренко (Федоренко, 2012) та О.Діденко (Діденко, 2013) досліджують комунікативні вміння та професійну підготовку працівників правоохоронних органів. Багато науковців приділили увагу питанню формування професійної мовно-комунікативної компетенції студентів як філологічних, так і нефілологічних спеціальностей, однак окремих досліджень, які 6 стосувалися розгляду формування та вдосконалення мовної особистості фахівця сфери цивільного захисту, поки що немає.

Метою статті $€$ аналіз мовленнєвої комунікації як фактору професійної успішності державних службовців сфери цивільного захисту та надання пропозицій щодо можливих варіантів їхньої мовленнєвої підготовки на засадах компетентнісного підходу в умовах функціонального навчання. У розвідці наводяться факти, що є результатом спостережень та моніторингу поточних інформаційних даних. Вони дають підстави авторам говорити про необхідність поліпшення навичок спілкування державною мовою фахівців сфери цивільного захисту та розвитку їхньої професійно-комунікативної компетентності, структура якої $€$ досить розгалуженою. Ії̈ складником може бути, наприклад, володіння всіма членами групи єдиною системою значень, що включає не лише значення слова, а й значення ситуації, у якій це слово застосовується, також знання основних правил ефективної комунікації, які ґрунтуються на комунікативних ознаках культури мовлення. Цей список 
можна продовжувати, але це тема наступного дослідження. У даній розвідці зупинимося на «основних правилах» та дамо практичні рекомендації, систему вправ і завдань для формування й поліпшення лише однієї 3 виокремлених ознак ефективної комунікації.

Методи дослідження. Проблеми комунікації досліджують науковці 3 різних наукових середовищ. Останнім часом у науковому вітчизняному просторі почала формуватися комунікативна лінгвістика. Тісні контакти ії з семіотикою, прагматикою, соціологією, психологією, лінгвістикою, когітологією та іншими сферами гуманітарного знання зумовили глибоке проникнення методів цих наук у дослідження комунікативних процесів. У цьому дослідженні використовуємо метод спостереження з метою збору та обробки інформації про рівень сформованості зазначених компетенцій у фахівців ДСНС; метод моделювання - для розгляду професіограми сучасного фахівця ДСНС як цілісної системи, до складу якої входять мовні та комунікативні навички; загальнонаукові методи аналізу й синтезу дозволили визначити та схарактеризувати окремі факти й умови, важливі для здійснення ефективного спілкування, та надати рекомендації щодо засвоєння слухачами правил успішного мовлення.

Виклад основного матеріалу. Мовно/мовленнєво компетентна людина має відповідні знання та здібності, що дозволяють їй обґрунтовано судити про певну сферу діяльності й ефективно діяти в ній. Слід відзначити, що в останні роки поняття «компетентність» вийшло на загальнодидактичний і методологічний рівень. Необхідність формування ключових компетентностей відзначена в Національній стратегії розвитку освіти в Україні. Серед цих основних компетентностей названо й мовленнєву. Так, зокрема, відповідно до чинного стандарту вищої освіти за спеціальністю 281 «Публічне управління та адміністрування» серед переліку загальних компетентностей знаходимо і здатність спілкуватися державною мовою як усно, так і письмово, а серед спеціальних (фахових, предметних) компетентностей - здатність до соціальної взаємодії, до співробітництва й розв'язання конфліктів. До речі, ця комтентність займає першу позицію серед інших (Наказ міністерства освіти і науки України «Про затвердження стандарту вищої освіти за спеціальністю 281 «Публічне управління та адміністрування» для першого (бакалаврського) рівня вищої освіти», 2018).

Тож, як бачимо, володіння мовною і мовленнєвою компетенціями $є$ необхідною умовою набуття професійної компетентності в багатьох сферах. Беручи до уваги власні спостереження та сучасні наукові дослідження щодо формування окремих аспектів професійної компетентності майбутніх фахівців у різних сферах діяльності, можемо стверджувати, що вільне володіння мовними ресурсами дозволяє особистості більш успішно виконувати завдання, що пов'язані, наприклад, 
із навчальним процесом, також ефективно комунікувати зі своїми ровесниками, активно долучатися до громадського життя. Зазвичай такі люди й у професійному житті стають більш успішними, оскільки спроможні легко налагоджувати соціальну взаємодію, комунікацію з колегами по роботі, успішно проводити переговори будь-якої складності та вигідно представляти інтереси компанії чи певної структури.

Культура мовлення, безперечно, $є$ підґрунтям для формування мовленнєвої компетентності. Ця компетентність удосконалюється впродовж життя, адже мовлення $є$ одним із найважливіших показників розвитку кожної особистості й суспільства загалом. Тож досконале володіння мовою стає важливим компонентом професіограми фахівців багатьох сфер (Каленич, 2014, с. 72-76) і, звичайно ж, фахівців сфери цивільного захисту. Вважаємо, що ця якість $€$ особливо важливою для виокремленої категорії державних службовців у зв'язку зі специфікою їхньої діяльності, яка вимагає, щоб рішення в умовах надзвичайної ситуації швидко готувалися, ураховуючи, що дуже важливо, найсвіжіші та точні відомості про перебіг події, приймалися й реалізовувалися. Тому необхідною умовою успішного вирішення $\mathrm{HC} \in$ вміння донести до всіх учасників події - і тих, хто нею керує, тобто приймає певні рішення, і тих, хто виконує ці рішення - інформацію так, щоб реципієнти їі правильно зрозуміли. Важливо пам'ятати, що комунікація передбачає прийняття, зрозумілість та осмислення інформації учасниками процесу. Тому перше завдання, що стоїть перед фахівцями, які задіяні в ліквідації НС, є доставка інформації за місцем призначення. Це $є$ питання, насамперед, технічних служб. 3 іншого боку, важливою умовою комунікаційного процесу є мовне та мовленнєве оформлення повідомлення, що передається.

Тож до основних вимог, які повинні сьогодні стояти перед фахівцями i, насамперед, керівниками досліджуваної служби, $\epsilon$ розвинене вміння ефективно комунікувати. На жаль, сучасна освіта, зокрема й функціональна, включає в себе незначний набір предметів, що розвивають комунікативні особистісні характеристики в людині, при цьому існує постійна загроза їхньої редукції на користь спеціальних дисциплін. Такий стан речей, на нашу думку, потребує уважного вивчення й адекватних змін.

На цьому етапі, одним із шляхів вирішення проблеми, на нашу думку, може стати впровадження занять із публічної комунікації в процес функціонального навчання. Згідно 3 «Порядком проведення навчання керівного складу та фахівців, діяльність яких пов'язана з організацією і здійсненням заходів з питань цивільного захисту» функціональне навчання «це навчання осіб, які за класифікацією професій належать до керівників, професіоналів і фахівців, з метою набуття та систематичного оновлення спеціальних знань, умінь і навичок з питань цивільного захисту» (Постанова Кабінету Міністрів України «Про затвердження Порядку проведення 
навчання керівного складу та фахівців, діяльність яких пов'язана з організацією і здійсненням заходів з питань цивільного захисту», 2013).

Підготовка та перепідготовка спеціалістів для цієї служби вимагає компетентнісного підхіду, який є сьогодні одним із актуальних підходів до формування професіонала. Він передбачає розвиток у двох взаємозумовлених вимірах: особистісному та професійному. Увага зосереджується на особистісно-психологічних структурах людини, це передбачає розширення світогляду, корекцію та подолання стереотипів, трансформацію цінностей, розвиток і вдосконалення таких поведінкових компетенцій, як ведення переговорів, залагодження конфліктів, відкритість, орієнтація на результат, розуміння цінностей інших, етичність, толерантність. Досягненню цієї мети може послужити вміння комунікувати.

Комунікабельність є важливим корпоративним ланцюжком будь-якої сфери. Результатом же невміння спілкуватися $є$ непорозуміння, плутанина, що веде до втрат як у матеріальному, так і духовному планах. 3 огляду на це, така риса має посісти важливе місце в переліку професійних компетентностей фахівців досліджуваної сфери. Однак, проаналізувавши лише кілька виступів представників сфери цивільного захисту, які $\epsilon$ у відкритих джерелах, наприклад, на каналі «Ютуб», можна помітити, що керівникам усіх рівнів важко висловлювати свої думки відкрито й точно, тому в їхньому мовленні з'являються непотрібні паузи, слова-паразити, якими намагаються заповнити зупинки в мовленні, лексичні, фонетичні помилки. Ці висновки також підтверджуються результатами опитування, яке було проведено серед слухачів курсів підвищення кваліфікації. Ми отримали відповіді, у яких слухачі зазвичай говорять, що виступ перед аудиторією викликає в них стрес, страх, який вони не можуть перебороти, підготовлені тексти забуваються, тому виходом вони вважають читання тексту з папірця чи зі слайдів презентації, або ж намагання скоротити свій виступ до мінімуму, що шкодить якості та ефективності повідомлення. У цій ситуації важливо пам'ятати, що це проблема, яку можна і потрібно вирішувати, адже висловлювати свої думки так, щоб інформувати й переконувати слухачів, можна навчитися.

Для вироблення ефективного стилю спілкування людина повинна знати свої особливості - як позитивні, так і негативні. Ефективне спілкування залежить від багатьох факторів, зокрема, від виду повідомлення, яке потрібно передати, контексту, у якому воно передається, типу аудиторії, 3 якою відбувається спілкування, та мети, яка ставиться. Важливе місце в цьому переліку посідає й наявність у списку компетентностей фахівця зазначеної галузі основних комунікативних ознак культури мовлення, зокрема, - це правильність, точність, логічність, змістовність, доречність, багатство, виразність, чистота мовлення. Цей перелік не є вичерпним і його можна розширювати, деталізуючи кожен із цих пунктів. Дослідженням означених 
складників у динаміці та різних комбінаціях, залежно від умов і ситуацій спілкування, та знаходженням технологій для запровадження їх у мовлення займається риторика (Мацько та Мацько, 2003).

Зважаючи на такий широкий список компетенцій, розуміємо, що запропонувати універсальний рецепт ефективного спілкування дуже складно - усі оратори відрізняються один від одного, а кожна авдиторія має свої очікування й потреби. Тому з метою скорочення часу та для чіткішої структурованості матеріалу ми виокремлюємо три основні правила ефективного мовлення, які для оволодіння навичками комунікації необхідно засвоїти насамперед. До цих правил, слідом за Д. Льюїсом (Льюис, 2002), який визначає їх, як жорсткі, ми відносимо вміння викласти свою думку чітко, зрозуміло й переконливо. У контексті функціонального, отже, зазвичай короткотермінового навчання важливим, на нашу думку, $\epsilon$ те, що такий підхід дає можливість надати практичні поради щодо розвитку та вдосконалення необхідних умінь і навичок під час роботи в авдиторії. Зі свого боку, це збільшить ефективність та полегшить самостійну роботу слухачів. Вважаємо, що це також допоможе вдосконаленню знань, умінь та навичок спілкування державною мовою.

У теоретичному вимірі чіткість, зрозумілість та переконливість - це комунікативно-стилістичні якості мовлення, які $€$ взаємопов'язані, тож у лінгвістичній науці вони диференціюються тільки узагальнено. Усе ж задля практичних цілей кожну з цих ознак варто аналізувати й розкривати окремо та запропонувати певні практичні рекомендації, які допоможуть виробити відповідні навички.

Для прикладу, зупинимося на методиці опрацювання та засвоєння одного з цих жорстких правил успішного мовлення більш детально. Зокрема, розглянемо чіткість мовлення.

Чіткість мовлення - це властивість мовлення, що відповідає значенню прикметника «чіткий», тобто розбірливий, виразний, ясний для розуміння тощо. Чіткість мовлення передбачає, насамперед, чітку вимову кожного звуку. Щодня ми зустрічаємося та спілкуємося з людьми, мова яких недбала, тому під час мовлення, особливо у формі монологу, у ній важко вловити думку, оскільки слова «наскакують» одне на одного, закінчення, ніби «з'їдаються», а деякі звуки або зовсім не чуються, або ж вони замінюються іншими варіантними фонемами. Звичайно, особа, яка відповідно до вимог фаху повинна вміти чітко передати інформацію, не може мати таких вад мовлення. Тож з метою вироблення чіткості мовлення на заняттях з публічної комунікації слухачам пропонується низка вправ. Ці вправи спрямовані на відпрацювання дикції і виконуються вони в два етапи:

1) пластична гімнастика органів мовлення, тобто вправи для розминки і тренування м'язів мовленнєвого апарату (рота, щелеп, губ, язика); 
2) вправи на тренування артикуляції голосних i приголосних у складах, словах, фразах (Основи школи юного диктора. Уроки літератури в школі за новою програмою).

Тож спочатку слухачам пропонується відпрацювати вміння керувати своїми органами мовлення, тобто вони вчаться надавати їм різні положення, відчуваючи при цьому рух кожного м'яза. Для досягнення результату можна використати загальноприйняті й відомі тренувальні вправи, якими послуговуються диктори:

1. На «раз» - розтягніть губи в усмішку, не оголюючи зубів; на «два»витягніть губи щільною трубочкою вперед («хоботок»); на «три», «чотири», «п'ять», «шість» - рухайте «хоботком» почергово вправо, вліво, вгору, вниз; на «сім» - знову усмішка; на «вісім» - вихідне положення. Вправу треба повторити 3-4 рази.

2. Вимовте артикуляційно виразно, але абсолютно беззвучно (як у сурдоперекладі) кілька фраз із будь-якого тексту. (Цю вправу з метою самоконтролю ліпше виконувати перед дзеркалом). При повторному виконанні вправи візьміть інший текст.

3. Вправа на тренування м'язів щелеп. Поставте лікті на стіл і обіпріться підборіддям на кулаки. Артикуляційно чітко читайте будь-який текст. При цьому ви повинні напружувати м'язи нижньої шелепи, рух якої обмежують ваші руки. Намагайтеся в цьому положенні досягати чіткої вимови. Ця вправа допоможе позбутися так званого «щелепного затиснення» (К. Станіславський), яке призводить до млявості мовлення.

4. Тренування губ. Вправа для верхньої губи: вимовляйте з чіткою артикуляцією: [гл], [вл], [вн], [тн]. Вправа для нижньої губи: вимовляйте з чіткою артикуляцією: [кс], [гз], [вз], [бз].

5. Вправи на розвиток м'язів язика:

а) висуньте язик і активно порухайте ним вліво, вправо, вгору, вниз; б) зробіть по кілька колових рухів висунутим язиком почергово в різних напрямках;

в) злегка висуньте язик і зробіть його широким, потім вузьким, потім чашечкою (злегка піднявши кінчик і бічні краї);

г) злегка піднятим напруженим кінчиком язика «почистіть» верхні зуби ззовні і зсередини, а тепер кожен зуб «пошліфуйте» язиком у напрямку від його внутрішнього боку до зовнішнього і навпаки;

д) тепер пружним язиком робіть уколи почергово в праву - в ліву щоку (Основи школи юного диктора. Уроки літератури в школі за новою програмою).

Наголошуємо, що ці вправи важливо спочатку відпрацювати на занятті, щоб слухачі засвоїли техніку їх виконання, а вже потім запропонувати виконувати їх самостійно до отримання потрібного результату: коли мовець відчує легкість у роботі артикуляційного апарату, 
що допоможе йому без жодних проблем, вільно й чітко вимовляти всі звуки як окремо, так і в складних поєднаннях.

Після цих вправ доцільно перейти до наступного етапу тренувальних вправ, який спрямований на вироблення чіткої дикції. Тут варто запропонувати слухачам вправи з читання, а далі й переказування напам'ять різних прислів'їв, приказок і, особливо, скоромовок, як, наприклад:

1. Летів перепел перед перепелицею, перед перепеленятами.

2. Карл у Клари вкрав корали, а Клара у Карла вкрала кларнет.

3. Ми плакати - не плакали: нам плакати нема коли.

4. Ніхто нашого паламаря не перепаламарює.

5. Дзижчить над житом жвавий жук, бо жовтий він вдягнув кожух.

6. Жовтий жук купив жилет, джемпер, джинси та жакет.

7. В горішнику горішина горішками обвішана.

8. Мішок на мішку - мішки в порошку. Порошок, як борошно, від борошна порошно.

9. В сінокосах, в срібних росах заросився бусол босий.

10. Босий хлопець сіно косить, босі ноги роса росить.

11. В ямі не спиться вусатому сому. Сому вусатому сумно самому.

12. Хитру сороку спіймати морока, а на сорок сорок - сорок морок (Основи школи юного диктора. Уроки літератури в школі за новою програмою).

Важливо зазначити, що роботу з цими реченнями слід починати 3 повільного читання вголос, зосереджуючи увагу на правильній вимові кожного звуку. Цим вправам також варто приділити увагу під час аудиторної роботи для засвоєння правил і принципів роботи 3 артикуляцією звуків задля досягнення чіткої дикції. Під час роботи з цією групою вправ використовуються інтерактивні форми навчання, зокрема, робота в міні-групах, під час якої комунікатори перевіряють і оцінюють вимову окремих складів, слів, речень один одного. Після цього можна запропонувати вибрати переможця у своїй групі. Далі переможці виступають перед авдиторією, яка оцінює ці виступи за такими, наприклад, критеріями: чіткість вимови кожного звуку; правильність вимови кожного звуку; загальне сприйняття звучання озвученого відрізку мовлення.

Загальні поради для того, щоб досягти бажаного результату, можуть складатися з таких пунктів: а) потрібно навчитися уважно стежити за вимовою кожного звука та, до досягнення чистоти артикуляції, не захоплюватися швидкістю читання; б) темп читання, наприклад, скоромовок, можна буде прискорити лише тоді, коли мовець відчує легкість у вимові; в) пам'ятати, що основне завдання оратора не швидкість, а чіткість мовлення, яке забезпечується правильною артикуляцією, яка, зі свого боку, досягається регулярними тренуваннями; г) мовцю важливо виробити звичку - перед публічним виступом робити коротку розминку органів мовлення. 
Висновки та перспективи подальших наукових розвідок. Отже, виходячи з вищесказаного, можемо говорити про важливість та необхідність формування у фахівців сфери цивільного захисту знань, умінь і навичок володіння державною мовою. Адже правильне та швидке рішення конкретної посадової особи сприятиме економії ресурсів та часу на вирішення професійних завдань. Оскільки фахівці сфери цивільного захисту повинні мати здатність працювати в особливих умовах у разі виникнення надзвичайних ситуацій, то під час їхньої мовної підготовки це повинно бути враховано. Уміння адекватно та вчасно прийняти рішення, сформулювати його й озвучити сприятиме економії ресурсів та часу на ліквідацію наслідків НС, зменшенню матеріальних збитків та, що найважливіше, уникненню людських жертв.

Перспективи подальших розвідок у цьому напрямі $\epsilon$ досить широкими. У найближчий час планується зробити детальний аналіз визначених, але не розглянутих у цій статті правил успішного мовлення, зокрема таких ознак, як зрозумілість та переконливість, і розробити методику їх опрацювання та засвоєння. Наступним кроком у цьому напрямку може стати розробка структури професійно-комунікативної компетентності фахівців сфери цивільного захисту та окреслення шляхів ії вдосконалення.

\section{ЛІТЕРАТУРА}

Діденко, О. В. (2013). Лінгвосочіокультурна компетентність майбутніх офріцерівправоохоронців: зміст, структура та особливості. Вісник Національної академії Державної прикордонної служби України. Серія: Педагогіка (електронне видання), 2 (Didenko, O. V. (2013). The linguistic socio-cultural competence of the future law enforcement officers: content, structure and features. Bulletin of the National Academy of the State Border Guard Service of Ukraine. Series: Pedagogy (electronic edition), 2. Retrieved from: www.irbis-nbuv.gov.ua/).

Каленич, В. (2014). Культура мовлення як чинник журналістської майстерності. Український інформаційний простір, 3, $72-76$ (Kalenych, V. (2014). Culture of speech as a factor of expertise in journalism. Ukrainian Information Space, 3, 72-76).

Льюис, Д. (2002). Тренинг эффективного общения. М.: экCMO-Пресс (Lewis, D. (2002). How to get your message across. $M .:$ EKSM O-Press).

Мацько Л. І., Мацько, О. М. (2003). Риторика. Київ: Вища школа (Matsko, L. I., M atsko, O. М. (2003). Rhetoric. Kyiv: Higher School).

Наказ міністерства освіти і науки України «Про затвердження стандарту вищої освіти за спеціальністю 281 «Публічне управління та адміністрування» для першого (бакалаврського) рівня вищої освіти (від 29.10. 2018 № 1172). (Order of M inistry of Education and Science of Ukraine "On approval of the Standard of Higher Education in specialty 281 "Public Administration" for the first (bachelor) level of higher education" (№ 1172, October, 29, 2018). Retrieved from: https://mon.gov.ua/ua/npa/

Основи школи юного диктора. Уроки літератури в школі за новою програмою. Режим доступу: http://liturok.in.ua/vurazchut/teoria/tehmov/7-vdpracyuvannya-chtkoyidikcyi.html (The basics of training of a young speaker. Literature lessons at school for 
the new programme). Retrieved from:

http://liturok.in.ua/vurazchut/teoria/tehmov/7-vdpracyuvannya-chtkoyi-dikcyi.html

Пентелюк, М. (2010). Компетентнісний підхід до формування мовної особистості в євроінтеграційному контексті. Українська мова і література в школі, 2, 2-5 (Penteliuk, M. (2010). Competence approach to the developing of a linguistic personality in the Euro Integration Context. Ukrainian language and literature at school, 2, 2-5).

Постанова Кабінету Міністрів України «Про затвердження Порядку проведення навчання керівного складу та фахівців, діяльність яких пов'язана з організацією і здійсненням заходів з питань цивільного захисту» (від 23 жовтня 2013 p. № 819). (Resolution of the Cabinet of M inisters of Ukraine "On approval of the procedure of training the managerial personnel whose activity is related to the organization and implementation of civil protection measures (October, 23, 2013 № 819)". Retrieved from: https://zakon.rada.gov.ua/go/819-2013-п

Розпорядження Кабінету Міністрів України «Про схвалення Стратегії реформування системи Державної служби України з надзвичайних ситуацій» від 25 січня 2017 $p$. № 61-p. (Resolution of the Cabinet of Ministers of Ukraine "On Approval of the Strategy for Reforming the System of State Emergency Service of Ukraine" №. 61-p. (January 25, 2017). Retrieved from: https://zakon.rada.gov.ua/

Федоренко, О. І. (2012). Види комунікативних вмінь та їх роль у професійній діяльності працівників правоохоронних органів. Вісник Національної академії Державної прикордонної служби України. Серія: Педагогіка (електронне видання), 1 (Fedorenko, 0.I. (2012). Types of communicative skills and their role in the professional activities of law enforcement officials. Bulletin of the National Academy of the State Border Guard Service of Ukraine. Series: Pedagogy (electronic edition), 1. Retrieved from: www.irbis-nbuv.gov.ua/).

Winkler, R. (2004). Kompetencja komunikacyjna pracowników. Zeszyty Naukowe. Akademia Ekonomiczna w Krakowie, 647, 77-86. (Communication competence of employees. Zeszyty Naukowe. Akademia Ekonomiczna w Krakowie, 647, 77-86). Retrieved from: http://bazekon.icm.edu.pl/

\section{PEЗЮМЕ}

Гайович Галина, Шихненко Екатерина. Пути усовершенствования навыков коммуникации на государственном языке специалистов сферы гражданской защиты.

Целью статьи является анализ речевой коммуникации как фрактора профрессиональной успешности специалистов среры гражданской защиты, а также внесение предложений относительно вариантов их речевой подготовки на основе компетентностного подхода в условиях функционального обучения. Использованы методы наблюдения, моделирования, анализа и синтеза. Утверждается, что свободное владение государственным языком является особенно важным для государственных служащих сфреры ГСЧС в связи со спецификой их деятельности, которая требует, чтобы решения в условиях чрезвычайной ситуации быстро принимались с учетом самых свежих и точных сведений о ходе события, оперативно утверждались и реализовывались.Дальнейшие исследования могут быть направлены на разработку структуры профрессионально-коммуникативной компетентности специалистов среры гражданской защиты и определение путей ее совершенствования.

Ключевые слова: профессионально-коммуникативная компетентность, языковые знания, речевая коммуникация, функциональное обучение, компетентностный подход. 


\section{SUMMARY}

Gaioyych Halyna, Shykhnenko Kateryna. Ways of improving communication skills in a state language of the civil protection specialists.

The paper deals with the issue of SES (State Emergency Service) professionals' training and their competences development, in particular language and verbal ones. The urgency of the issue stems from changes in social life. Verbal communication is analyzed as a key to career success of civil protection specialists. The focus in the present article is on the individual who acts in a discursive space under specific communicative circumstances of emergency. Some facets of the specialists' verbal activity are considered, and particular approaches to improving the quality of their learning achievements during functional training are defined. It is highlighted that the fluency in the national language is particularly important for SES public servants due to the specific nature of work which requires quick emergency decision-making based on the up-to-date and accurate information on the course of the event, and its prompt approval and implementation. This gives grounds to talk about the importance of communication skills. It is emphasized that communication includes acceptance, comprehension of the relevant information as well as reflection on it by all the participants. Thus, essential requirement for successful decision-making under emergency conditions is information delivery from and to the sight of emergency event, and the wording of it to the recipient in precise and understandable way to be perceived clearly.

In the paper, the basic rules for effective communication are defined, and some patterns with practical recommendations as well as a system of training exercises are introduced to be used to improve the distinguished features. According to the authors' view, it is important that in the context of functional and usually short-term training, such an approach provides an opportunity for practical advice on the development and improvement of crucial skills during classroom hours. It will increase the efficiency and facilitate the independent work of the students.

Further studies will be devoted to the development and improvement of the structure of professional and communicative competence of civil protection employees.

Key words professional and communicative competence, language skills, verbal communication, functional training, competence approach.

удк 378.147:37.026:615.08

Ніколь Дмітрієва

Міжнародний науково-технічний університет імені академіка Юрія Бугая ORCID ID 0000-0001-6492-3371

Юлія Копочинська

Міжнародний науково-технічний університет імені академіка Юрія Бугая ORCID ID 0000-0001-5018-3747

DOI 10.24139/2312-5993/2019.07/195-206

\section{ОГРАНІЗАЦІЯ МІЖПРОФЕСІЙНОЇ ОСВІТИ МАЙБУТНІХ ФАХІВЦІВ 3 ФІЗИЧНОÏ TЕРАПIÏ ТА ЕРГОТЕРАПIÏ}

Метою статті є огляд методів організації міжпрофесійної освіти фахівців з фрізичної терапії та ерготерапії. При проведенні дослідження був здійснений аналіз 